\title{
BRITISH HILL STATIONS IN SOUTH ASIA AND MAINLAND SOUTH EAST ASIA: BRITISH INDIA, CEYLON, BURMA AND BRITISH MALAYA: A COMPARATIVE STUDY
}

\author{
Robert C. M. Weebers \& Hanizah Idris \\ Department of Southeast Asian Studies \\ Faculty of Arts and Social Sciences, Universiti Malaya \\ (robertcmweebers@gmail.com)
}

\begin{abstract}
Hill stations in South Asia and Mainland South East Asia in British India, Ceylon, Burma and British Malaya were established in the $18^{\text {th }}, 19^{\text {th }}$ and $20^{\text {th }}$ century by the British who governed these countries. The objective of this paper is to show the similarities of fifteen hill stations in these countries in terms of location and size, city ranking, purpose and layout, facilities and architecture. The purpose to found a hill station was to escape from the soaring heat in the plains and to recover from tropical diseases contracted and therefor located in the mountains or hills where the air is cool at a height between 2,000 and 9,000 feet. The size of the stations is between 408 (?) and 600 square miles. Some hill stations had the function of the capital of the government of a country or specific area. The hill station possessed characteristics and facilities of the British Home Counties: climate, clubs, golf courses, racecourses, lakes, and architecture in the British (Gothic Revival, Tudor Revival, Elizabethan Renaissance Revival, Victorian or Swiss Gothic) style, botanical gardens, vegetation and life style.
\end{abstract}

Key words: hill stations, South Asia, Mainland South East Asia, British India, Ceylon, Burma, British Malaya

\section{Introduction}

In this study, the characteristics of fifteen British hill stations will be analysed, which were established from $18^{\text {th }}$ to $20^{\text {th }}$ centuries in South East Asia and 
Mainland South East Asia in British India, Ceylon, Burma and British Malaya. In South East Asia in British India eight hill stations (in the North: Simla and Mussoori, in the East: Darjeeling and Kalimpong, in the West: Lonavala and Mahabalishwar and in the South: Kodaikanal and Ootacamund and in Ceylon one hill station (Nuwara Eliya). In Mainland Southeast Asia in Burma two hill sta tions (Maymyo (Pyin Oo Lwin) and Kalaw) and British Malaya four hill stations (Penang Hill, Fraser's Hill, Maxwell's Hill and Cameron Highlands). The analyses will be done according to five criteria. The criteria will be incorporated in characteristics and are as follows: 1 . location and size, 2. city ranking, purpose and layout, 3. facilities, 4. architecture and 5. surrounding areas.

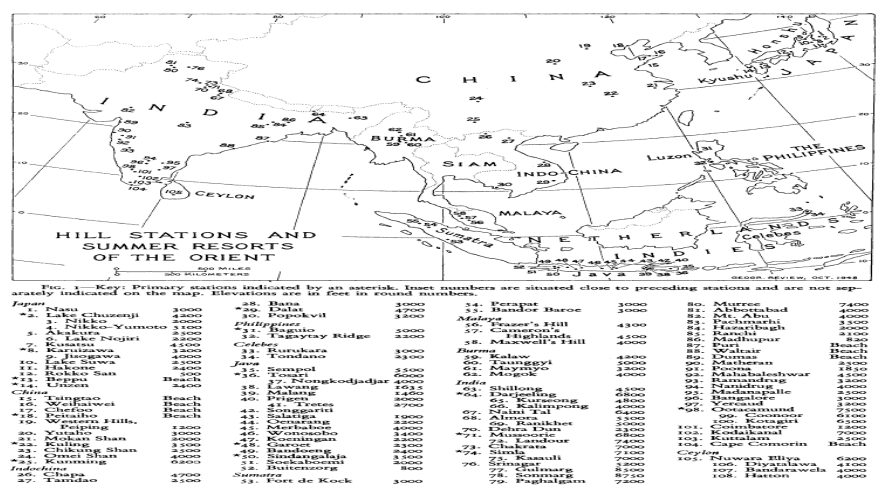

Figure 1. Hill stations and summer resorts of the Orient. (C) Spencer and Thomas (1948).

These hill stations were founded between 1788 and 1925. Simla around 1841, Mussoorie around 1825, Darjeeling in 1828, Kalimpong after 1864, Lonavala in 1871, Mahabaleshwar in 1828, Kodaikanal in 1845 and Ootacamund in 1819, Nuwara Eliya established in 1847, Maymyo established in 1896 and Kalaw in the 19 th $^{\text {th }}$ century, Penang Hill established in 1788, Maxwell's Hill in 1880, Fraser's Hill in 1922 and Cameron Highlands in 1925.

Hill stations were mostly a $19^{\text {th }}$ century phenomenon, established between 1820 and 1855, associated with the British in British India, though in the Dutch East Indies hill stations, Bogor and Bandung, were established as well as in French Indochina where at the beginning of the $20^{\text {th }}$ century Dalat in Viet Nam and the Philippines, ruled by the Americans, Baguio, were established (Crossette, 1999a). Hill stations were retreats as what seaside resorts, spas, and great mountain lodges were in Europe and the United States. In colonial Asia, the high altitude hill station, at 5,000 to 8,000 feet above sea level, was more than just a resort it was a medical centre. The site was beyond the reach of mosquitoes, though it was not known until the end of the $19^{\text {th }}$ 
century that insects carried the malaria parasite. The hill station was a retreat where the colonial could retreat in a European town with European architecture and facilities with a European character: the club, the library and the village church.

\section{British India}

Characteristics: 1. location and size, 2. city ranking, purpose and layout, 3. facilities, 4. Architecture and 5. surrounding areas

Lord William Bentinck authorised the establishment of Simla in 1819. Simla is at the height of 7,000 feet high, the capital city of the British Indian state of Himachal Pradesh and 10 square miles in size [Lieutenant-General Lord William Henry Cavendish-Bentinck (1774-1839). Known as Lord William Bentinck. A British soldier and statesman. Bentinck served as GovernorGeneral of British India from 1828 to 1835]. The city ranking and purpose of the town was the political capital of British India in the hills as the residence of governors-general, lieutenant-governors, commanders-in-chiefs and high authorities (Clarke, 1881). The layout of the town was characterised by a Mall and roads with typical English names as Circular Road, Cart Road and Ridge Road (Revised Heritage Report (4), (2008). The buildings were placed as to maximise the inlet of sunlight and to take advantage of the scenic beauty.

The facilities of the town were the observatory, large dispensary, bank, library, hotels, assembly rooms, type copper plate and lithographic printing house and many shops (Clarke, 1881). Architecture in Simla was diverse and in different styles (Kennedy, 1996). The post office was in the British Tudor Revival style (Kennedy, 1996), the fortress-like telegraph office, the Swiss Gothic Ripon Hospital, the large stone courthouse and a public office for administrative or judicial business of the deputy commissioner, the publicworks building, the town hall, a Victorian Gothic complex that housed municipal offices, the police station, an assembly hall, a Masonic hall, the Gaiety Theatre, the foreign office in the Swiss chalet style and the Vice regal Lodge. (a castle of gravy limestone in the Elizabethan Renaissance Revival style) (Kennedy, 1996). In the surrounding areas vegetables and a Shimla variety of green chillies were grown.

A shooting lodge was constructed in 1825, at the side where now is the city of Mussoorie, after the British military officer Captain Young [the "discoverer" of Mussoorie, who was also the Commandant of the first Gurkha battalion raised by the British after prevailing in the Gurkha War] and Mr Shore [the resident 
Superintendent of Revenues at Dehradun] Explored the areas surrounding Dehradun [The capital city of the state of Uttarakhand in the northern part of India]. Mussoorie is at the height of 6,170 feet and 25 square miles in size. The city ranking and purpose of Mussoorie were as a popular holiday resort, centre for European education and one of the earliest centres for cutting trees for export to the plains (Kennedy, 1996). The town had natural beauty and biological diversity. The layout of the town was characterised by the Mall, which stretches from Picture Palace at the eastern end of the Public Library at the western end. The main facility of the hill station was the botanical garden. The architecture in Mussoorie included churches as Christ Church built, in 1836, in the British Gothic Revival style, and the Central Methodist Church built, in 1885, in a massive stone. In the surrounding areas - are Dense Sal, Coniferous, Rhododendron, Oak and Deodar forests and huge mountain peaks. The location of the hill station of Darjeeling was established by J.W. Grant [The commercial resident at Malda in Northern Bengal] and MajorGeneral G.W.A Lloyd [Commander of the Singapore Division in the Bengal Army] while surveying the boundary between Nepal and Sikkim (Clarke, 1881). Darjeeling is situated at the height of 9,000 feet, on a ridge of the Great Sinchal mountain, due north of Calcutta (Clarke, 1881), and 4.08 square miles of size. The city ranking and purpose for the settlement of Darjeeling were that it was the summer capital and holiday destination for East-British India company agents during British times (Crossette, 1999a). Darjeeling was the place, which produced most of British India's black tea. The Darjeeling territory was an important trading post situated between Nepal, Tibet and Bhutan on one of the natural routes to Central Asia. It included gold dust, iron, copper, lime, woods, tea, wax, ginger, catechu, cassia, coffee, cotton, hemp, gunny cloth, rice, cardamoms, oranges, potatoes, ghee, hides, horns, musk, wool, chowries, blankets, woollen cloth and many other articles (Clarke, 1881: 534). From the colonial era on Darjeeling had many schools, educating Europeans, British Indians and Bhutanese (Crossette, 1999b). The layout of Darjeeling town was in three levels on the hills, and each level was connected to the other by steep, narrow roads. The Mall is the heart of Darjeeling town, and here the four main roads of the town meet. The main facility of the town was the Lloyd Botanical Garden, of fourteen acres, named after General Lloyd (Kennedy, 1996). The architecture of the town included a church, St. Andrew's Church, built in the British Gothic Revival style. Other buildings were the Baptist and Roman Catholic chapels, nunnery boarding, schools for boys and girls, public library, masonic lodge, hospital, treasury, jail, hotels and various shops (Clarke, 1881). Wooden-fronted buildings Swiss chalets with steep roofs, 
carved eaves and gables, complemented the solid stone British-style houses. In the surrounding areas were tea plantations.

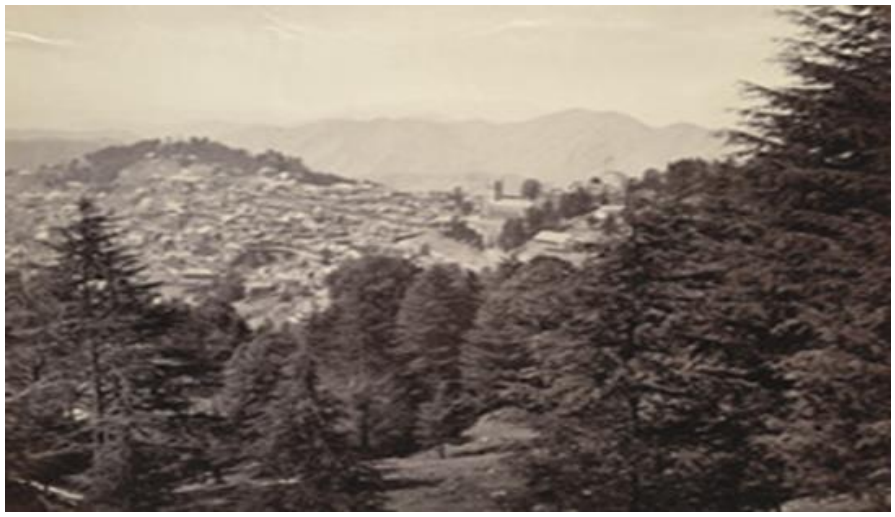

Figure 2. Hill station of Simla, 1865

(C) The British Library

The British developed Kalimpong after the Anglo-Bhutan War in 1864 as an alternative hill station to Darjeeling. The first recorded mention of the town was a short reference made by Ashley Eden, a government official with the Bengal Civil Service. Kalimpong is located in the Shiwalik Hills or Lower Himalaya in the Indian state of West Bengal at an elevation of 4,101 feet (Biswas, 2013) and 407.9 square miles in size. The city ranking and purpose for Kalimpong were that it was known for educational institutions and as a gateway in the trade between Tibet and British India before China's annexation of Tibet and the Sino-British Indian war (Biswas, 2013: 43). The layout of Kalimpong is similar to Darjeeling but on a smaller scale (Kishore, 2003). The main facility of the town was horticulture, and the town had a flower market notable for the wide choice of orchids. The architecture was characterised by buildings in different styles. Dr Grahams Home, an orphanage and school, has a chapel with elements, which remind of a Scotland parish, with the grey slate, spire and fine stained-glass windows. St Teresa's Church, a missionary church, built in 1929 by Swiss Jesuits, has elements, which remind of a Bhutanese Gompa [Gompas, or gönpas, "remote place". Tibetan monasteries or temples]. MacFarlane Church, built in 1870 has woodbuttressed Gothic interiors. Morgan House, a building of two stories, built in the 1930s in the British Gothic Revival style (Desai, Desai \& Lang, 2012). In the surrounding areas were nurseries, which exported Himalayan grown flower bulbs, tubers [Tubers are various types of modified plant structures that are enlarged to store nutrients. They are used by plants to survive the winter or dry months] and rhizomes [a continuously growing horizontal underground 
stem which put out lateral shoots and adventitious roots at intervals]. Lord Mountstuart Elphinstone discovered Lonavala hill station [John Elphinstone, 13th Lord Elphinstone and 1st Baron Elphinstone (1807-1860). A Scottish soldier, politician and colonial administrator. He was twice elected to the Parliament of the United Kingdom as a Scottish Representative Peer. His political career also included the governorships of Madras and Bombay]. Lonavala is located in the western part of the state of Maharashtra, in the western region of British India, situated southeast of Mumbai at an altitude of 2,050 feet above sea level, and had a size of about 15 square miles. The city ranking and purpose of the town were, because of the beauty and serenity of the area, for relaxation. Lonavala was famous for sweet hard candy known as "chikki". A Bazaar in the middle of town dominated the layout of the town. The facilities of the town were the numerous lakes in the proximity of the hill station, which carry the names Tugauli, Lonavala, Bhushi and Walvan. The town had no British architecture to speak of. Caves and a dense forest surrounded the town. In the surrounding area were Lonavala market and the botanical garden Ryewood Park

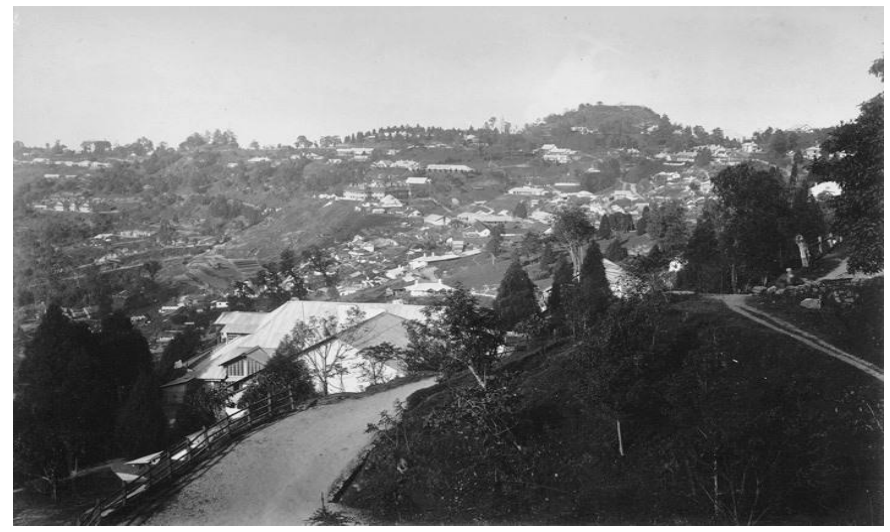

Figure 3. Darjeeling ca. 1880

After Sir John Malcolm, who founded Mahabaleshwar in 1828, a succession of Governors starting with Sir Elphinstone, Arthur Malet [Sir Charles Warre Malet, (1753-1815). The first Baronet. British Indian administrator and diplomatist. After filling various posts, including a mission to the great mogul, he was in 1785 appointed resident minister at Poona, at the court of the Peishwa. Subsequently, Malet was for some time acting governor of Bombay, an office which he held until 1798 when he retired from the service and returned to England], Carnac [Sir James Rivett-Carnac (1784-1846). 1st Baronet, Governor of the Bombay Presidency of British India from 1839 to 1842. Carnac served the East British India Company in British India from 1801 and was a 
director of the Company for various periods between 1827 and 1838 . He was elected a Fellow of the Royal Society in May 1838], Frere [Sir Henry Bartle Edward Frere (1815-1884), the first Baronet, British colonial administrator. He had a successful career in British India rising to become Governor of Bombay]. Moreover, many others became regular visitors. Mahabaleshwar, at the height of 4,500 feet (Kennedy, 1996) is a small town on a range of the Western Ghats (The Western Ghats or Sahyadri is a mountain range that runs parallel to the western coast of the Indian peninsula, located entirely in India), in the Bombay area and 52.95 square miles in size. The city ranking and purpose for Mahabelishwar were it became the principal hill station for the Bombay Presidency (Kennedy, 1996) and relaxation. The layout of the town was characterised by the Bazaar, in the centre of town, named Malcolm Peth (it is Scottish for a portion of land) after the British Governor of Bombay, Sir John Malcolm (1769-1833). He was a Scottish soldier, diplomat, East British India Company administrator, statesman, and historian. The facilities in town included a church, library, invalid garrison (Clarke, 1881), a sanatorium built in 1928, a polo ground and racecourse, and an artificial lake created for scenic beauty (Kennedy, 1996). The architecture was characterised by buildings in different styles. Babington House was in the shape of a cross with a deep veranda, elaborate metalwork railing and extensive outhouses (Kennedy, 1996). Another characteristic building was Government House, known as the Terracesa relatively small building in the midst of forests built in 1886 for the governor of Bombay. In the surrounding areas was one the few evergreen forests of British India.

In 1821, B. S. Ward [Lieutenant, Sub-Collector of Madura] climbed from his headquarters in the Kunnavan village of Vellagavi to Kodaikanal to survey the area on the hilly ranges of Palani [it is a town and a municipality in Dindigul district, Tamil Nadu, located about $100 \mathrm{~km}$ north-west of Madurai and $100 \mathrm{~km}$ South-east of Coimbatore and $60 \mathrm{~km}$ west of Dindigul]. Kodaikanal is a city located in the hills of the Dindigul district in the state of Tamil Nadu at the height of 6,998 feet and 8.28 square miles in size. The city ranking and purpose of Kodaikanal were the healthy climate and placement in beautiful hills (Ward, 1837) known for the rich flora, with big trees, cypress, eucalyptus and acacia were the dominant varieties. The layout of the town was such that the town was built along sunny slopes with a Mall with residences for the British and churches, clubs and civil buildings built along principal roads (Anand, 1997). The facilities of the town included lakes, parks and different waterfalls with a rich abundance of flora and fauna, several clubs and civil society organisations 
and 18-hole golf course. The architecture was in an American style of distinctive stone architecture. In the surrounding areas was a rich flora.

The discovery of the Nilgiri area, where the town of Ootacamund is located, is attributed to Wish and Kindersley assistants to John Sullivan [District Collector of Coimbatoire (1788-1855). Sullivan was credited to initiate the development the Nilgiri hills as a sanatorium for sick European soldiers in British India] (Emeneau, 1963). The town of Ootacamund is situated at the junction of the Eastern and Western Ghats [The Eastern Ghats. A discontinuous range of mountains along India's eastern coast and run from West Bengal state in the north, through Odisha and Andhra Pradesh to Tamil Nadu in the south passing some parts of Karnataka] at a higher point where the Nilgiri summits is over 8,000 feet high above the plains to the north and the east (Emeneau, 1963). In addition, on a plateau 40 miles long by 15 miles broad (600 square miles in size). The city ranking and purpose for Ootacamund were that it was the most important hill station founded by the British in South British India for Mysore State [from 1399-1947 the Kingdom of Mysore in South India; after 1947 the State of Mysore]. The town was the official summer retreat of the Madras Government during the British Raj [the British Raj was the rule of the British Crown in the Indian subcontinent between 1858 and 1947] to regain one's health and to withdraw for a holiday (Veale, 2007). The layout was characterised by a Mall with a cathedral, post office and government house. The town had a swamp through which a stream flowed which came down from the Public Gardens past Stonehouse Hill. The stream was dammed down, and by 1825, a twisting lake about two miles long was formed. The facilities of the town were a boat club founded in 1884-85 (Emeneau, 1963), a church, public gardens, meteorological observatory (Clarke, 1881) and a botanical garden, 55 acres large, laid out in 1847 by the Marquis of Tweeddale [Colonel Arthur Hay, 9th Marquis of Tweeddale (18241878); Scottish soldier and ornithologist]. The architecture was an eclectic mix of British Gothic Revival, Arts and Crafts and Swiss architecture. In the surrounding areas, there was agriculture, with the cultivation of "English vegetables" and "English fruits". Dairy farming has long been present in the area.

\section{Ceylon}

\section{Nuwara Eliya}

Characteristics: 1. location and size, 2. city ranking, purpose and layout, 3. facilities, 4 . architecture and 5. surrounding areas 
Sir Samuel White Baker (1821-1893) is a British explorer, officer, naturalist, big game hunter, engineer, writer and abolitionist. He is remembered as the discoverer of Lake Albert, as an explorer of the Nile in 1846 and interior of central Africa, and for his exploits as a big game hunter in Asia, Africa, Europe and North America. He spent weeks in Nuwara Eliya in 1847 recuperating from a malaria attack was so taken by the setting in a wet high altitude valley miles long that he decided to settle and build "a British town around my residence" (Crossette, 1999a). Nuwara Eliya is a city situated, in the hill country of the Central Province, Ceylon. The meaning of Nuwara Eliya is "city on the plain" or "city of light". The city is the administrative capital of Nuwara Eliya District, with a picturesque landscape and temperate climate associated with the mild climate in Europe. Located at an altitude of 6,128 feet, with a size of about 5 square miles. The city ranking and purpose of Nuwara Eliya was the widespread growing of vegetables, fruit and flowers and tea production. A convalescence centre was established (Crossette, 1999b). The layout of the town is characterised by a Central Market in the centre of the town with south of the market Victoria Park. A river "Nanu Oya" ran through the park, and the park has some lakes. Facilities included the golf course, trout streams, Victoria Park, and boating or fishing on Lake Gregory. Many of the buildings retain features from the colonial period such as the "Queen's Cottage", "General's House", "Grand Hotel", "Hill Club" and the Town Post Office. Many private homes still maintain old British-style lawns and gardens. British architecture in Nuwara Eliya was in an eclectic mix of revival styles of previous periods. From the Classical, Elizabethan, Jacobean, Scottish Baronial, British Gothic, Renaissance and Romanesque periods. In the surrounding areas of the hill station vegetables, fruit and flowers were grown.

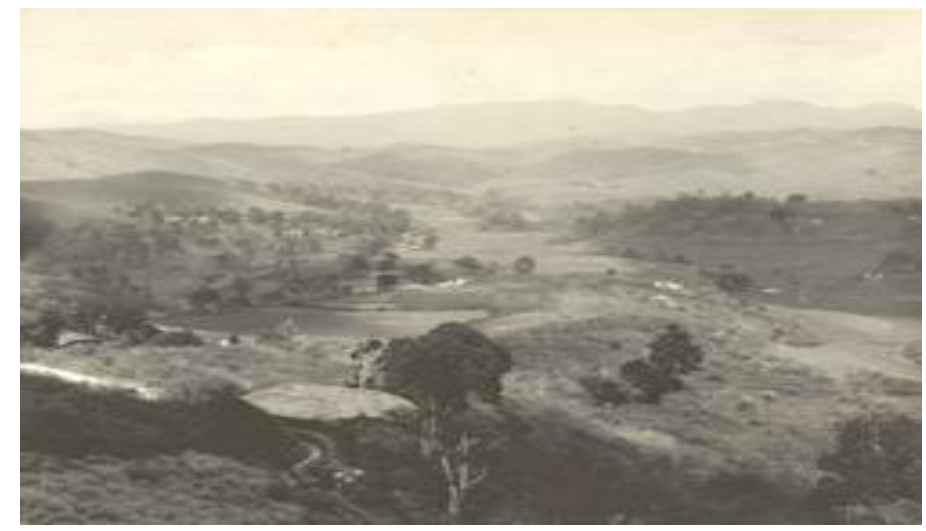

Figure 4. The Valley at Nuwara Eliya ca.1900 (C) The British Library 


\section{Burma \\ Characteristics: 1. location and size, 2. city ranking purpose and layout, 3. facilities, 4 . architecture and 5 . surrounding areas}

\section{Myamyo}

The town of Myamyo began as a military outpost, in 1896, established near a small Shan village situated on the Lashio-Mandalay trail between Nawnghkio and Mandalay. The settlement of Maymyo (Pyin Oo Lwin or Pyin U Lwin) was located 30 miles east of Mandalay in Mandalay Division, Burma, in the Shan Highland at an altitude of 3,510 feet with a size of 20 square miles, on a high tableland, stretching from Burma to the Salween River [a river, about 1,749 mile long, that flows from the Tibetan Plateau into the Andaman Sea in Southeast Asia] and from China to Siam. The British named the location Maymyo, literally May's Town in Burmese, after Colonel May [a veteran of the British Indian Mutiny and Commander of the Bengal Regiment temporarily stationed at the location of the town in 1887]. The city ranking and purpose for Maymyo was the town became the summer capital of British Burma because of the climate, and Maymyo was an important educational centre during colonial times, with the GEHSs (Government English High Schools) all based in the town. The layout of the town was characterised by a Mall with streets with typical English names: Downing Street, Church Road and Club Road and Charing Cross Road. Around the hills were little half-timbered cottages with names like "All in All", and "Fernside", with Cotswold gardens (Iyer, 1988). The facilities of the town were, in the centre of the settlement, the club overlooking polo grounds and fairways of a golf course and with a hundred miles of well-kept rides. Ladies' Mile, Five Mile Bottom and Rotten Row, a whole maze of pathways for a man or woman on a horse (Hunt, 1967). The architecture included buildings "Government House" and "Flagstaff House" (Hunt, 1967) a Post Office and Railway Station, St Joseph's Convent School and Boarding House "Candacraig" of the British Bombay Burmah TradingCompany, built in 1904, for their employees. In the town was the Church of the Immaculate Conception built in 1905 and All Saints Church built between 1912 and 1914. Architecture in the town was in the Tudor Revival style. The residential area had pinewoods, with English-style half-timbered houses standing back in large gardens (Mannin, 1955). In the surrounding areas were the National Botanical Gardens, established in 1915, and the adjacent Pyin Oo Lwin Nursery. Characteristic were the eucalyptus, silver oak and pine and on the slopes of the hills were the coffee plantations, flower and vegetable gardens and strawberry and pineapple orchards. 


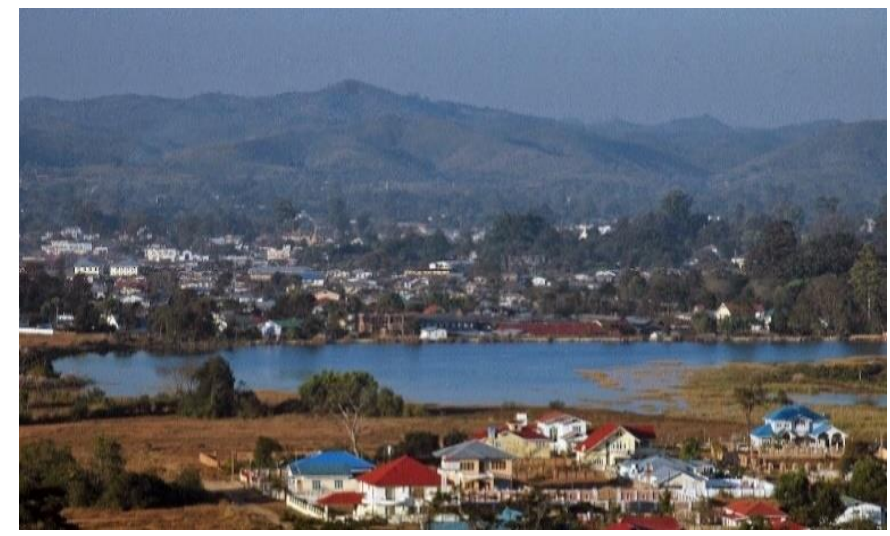

Figure 5. Maymyo (Pyin U Lwin), behind Kandawgyi Lake

C) Jim Goodman

\section{Kalaw}

The hill station of Kalaw was founded by Sir James George Scott was a journalist and colonial administrator who helped establish British colonial rule in Burma in the $19^{\text {th }}$ century. The population was a mix of Shan, British Indian Muslims, Bamars, Nepalis and Gurkhas (retired from British military service). Kalaw is a hill town in the Shan State [it borders China to the north, Laos to the east, and Thailand to the south, and five administrative divisions of Burma in the west] of Burma popular with the British during colonial rule. The hill station is located at an elevation of 4,330 feet and is sprawled over a large area. It is difficult to determine the exact size of the town. The city ranking and purpose of the hill station of Kalaw was a retreat from the heat of the plains. The layout of the small, not well developed, hill station was characterised by a few bungalows and one or two hotels (Spate, 1945). The main facility of Kalaw was the Inle Lake; a freshwater lake. The architecture of the town was dominated by the Catholic Christ the King Church and an Anglican Church built in 1906 located in the southwestern part of Kalaw. Bungalows bore the names "Tudor Rose", "Caritas Cottage", for vacationing nuns, and the Steels Brothers Company House from Steel Brothers Burma Trading Company Ltd. (Campagnac-Carney, 2010). The Methodist Missionary school, Kingswood High School, opened in 1928, named after the first Methodist school founded by John Wesley (1703-1791) who was an Anglican minister and theologian. He was credited with the foundation of the evangelical movement known as Methodism at Kingswood near Bristol (UK) in 1748. Tudor Revival style houses stood amongst British rose gardens. In the surrounding area were agricultural lands growing ginger, oranges, tea, cauliflower, and other 
produce. Limited wild, uncultivated areas existed in the area surrounding the Inle Lake.

\section{British Malaya}

Characteristics: 1. location and size, city ranking, purpose and layout, 3. facilities 4, architecture and surrounding areas

The oldest British hill station in British Malaya dated from 1788 when Captain Francis Light travelled on horseback to the top of the hill (Crossette, 1999b). Penang Hill area, 2,000 feet above sea level and small in size, is a complex of peaks and spurs connected by a ridge (Kam, 1992). The city ranking and purpose for Penang Hill was for health and relaxation, the tea plantation and the hill station has one of British Malaya's few original forests. The layout of the hill station was divided into geographical areas: the steep north, east, west, and south slopes. Part of the rainforest covers the whole central range of hills. On the east, slopes were farmland, houses, and the funicular railway and on the Crag/Lomond's/Richmond Ridges a low-density distribution of buildings. The spur of the Crag Ridge projects northward offered broad views out to the sea and the mainland (Penang Hill Resort, 1990). The main facility was Strawberry Hill and in the surrounding areas was a forest.

Maxwell Hill (1871-1959) was named after William George. Maxwell was a Colonial Administrator in British Malaya. Maxwell's Hill has located 10 $\mathrm{km}$ from Taiping Perak, 4.101 feet above sea level and equally small. The city ranking and purpose for Maxwell Hill were rest and convalescence (Penang Hill Resort, 1990). The facilities provided in this hill station were birdwatching and nature. The architecture in Maxwell Hill included bungalows "The Cottage" (1890), built in the Tudor Revival style, and "The Tea Garden House", an English-style bungalow. In the surrounding areas were tropical jungle and hills.

Fraser's Hill was named after Louis James Fraser, an entrepreneurial wanderer from Europe who worked as a mule-train operator, an opium smuggler, and tin miner. Fraser's Hill included seven peaks, with heights between 4,000 and 5,000 feet above sea level. The hill station covered about 0.54 square miles. The city ranking and purpose for the hill station of Fraser's Hill was relaxation. The facilities of the hill station were the country club, a golf course, water supply and a post office. The architecture was characterised by houses built in the Tudor Revival style with timber frames and local limestone blocks. In the surrounding area was one of British Malaya's few 
original forests, with a high level of biodiversity [it is the variety of different types of life found on earth. It is a measure of the variety of organisms present in different ecosystems] was first recognised by the botanist H. N. Ridley (a British botanist and geologist) in 1897. Two expeditions were organised in the area, which is now called Cameron Highlands, in the 1920s. Maxwell concluded that the area was comparable to Nuwara Eliya or Baguio in the Philippines.

Cameron Highlands is on a plateau, at the height of 4,921 feet, with the size of Singapore (275 square miles) in the Titiwangsa Mountain Range. The city ranking for Cameron Highlands was agriculture (vegetable farms) and tea plantations like the Cameron Bharat Plantation and the Sungai Palas Boh plantation. The purpose of the area was, as suggested in the 1927 Handbook to British Malaya that the highlands of Pahang might also become a retirement community for Europeans. The main town, at the centre of the hill station, is Tanah Rata. The purpose of Tanah Rata was the administrative centre for Cameron Highlands. The different parts of the specification of the layout of Tanah Rata were the circulatory part with roads, streets, and lanes. An educational/religious part with schools and churches. A built up part with bungalows and houses. Tanah Rata had one main thoroughfare and some side streets. The main facility was a golf course. The architecture in Cameron Highlands had buildings designed in the English Tudor Revival style and the black- and-white Tudor Revival style (Crossette, 1999a). Other buildings were designed in black and white, which is considered the black-and-white Tudor Revival style and architecture in the Chinese shop house style. In the surrounding areas of Cameron Highlands were agriculture (vegetable farms) and plantations with the Cameron Bharat Plantation and the Sungai Palas Boh plantation.

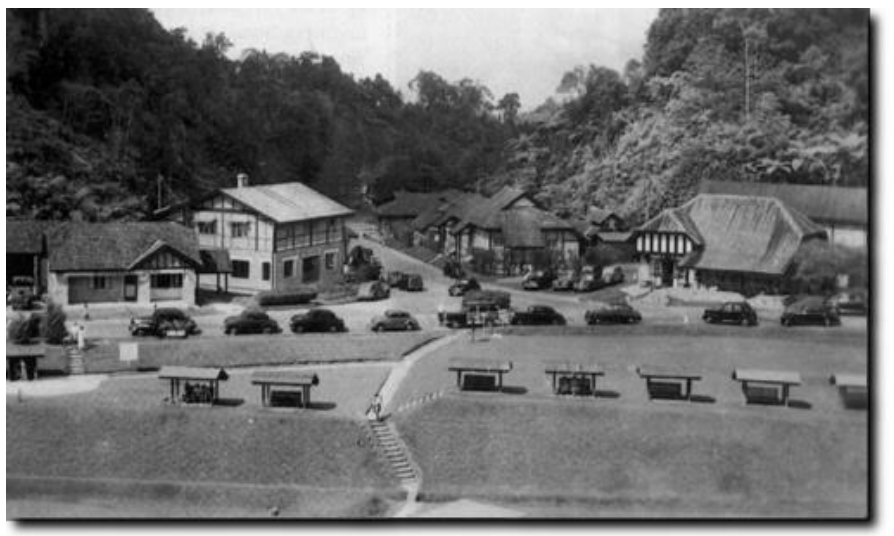

Figure 6. Fraser's Hill (C) The British Empire 


\section{Conclusion}

Hill stations in South Asia and Mainland South East Asia, in the countries discussed in this paper, were established in the $18^{\text {th }}, 19^{\text {th }}$ and $20^{\text {th }}$ century by Europeans who governed countries in these regions. The purpose to found a hill station was to escape from the soaring heat in the plains and to recuperate from tropical diseases contracted to which Europeans were so susceptible and did not have resistance. Hill stations had a sanatorium. All hill stations are located in the mountains or hills of the specific countries where the air was cool.

The hill stations are at a height between 2,000 and 9,000 feet. The highest located hill station in British India is Darjeeling at 9,000 feet, and the lowest is Lonavala at 2,050 feet above sea level. In Ceylon Nuwara Eliya is located at an altitude of 6,128 feet. In Burma, Maymyo is at the height of 3,510 feet, and Kalaw is located at an elevation of 4,330 feet. In British Malaya, Penang Hill is at 2,000 feet, and Maxwell's Hill is at 4,101 feet above sea level, Fraser's Hill is between 4,000 and 5,000 feet above sea level, and Cameron Highlands is at the height of 4,921 feet.

The size of the hill stations differ. In British India, hill stations had a size between 4, 08 square miles to 600 square miles. Simla had a size of 4,08 square miles to Ootacamund with a size of about 600 square miles. In Ceylon, Nuwara Eliya had a size of about 5 square miles. In Burma, Maymyo had a size of about 20 square miles. In British Malaya, hill stations were quite small except for Cameron Highlands with a size of 275 square miles.

Europeans inhabited Hill stations. Some hill stations had the function of the capital of the government of a country or specific area. Simla for the whole of British India, Mahabelishwar for Bombay or Ootacamund for Madras. Maymyo held that position for Mandalay in Burma. In British Malaya, that function was held by Cameron Highlands for Kuala Lumpur. A hill station had all the characteristics, attractions, and facilities of the home country. Climate, clubs, golf courses, racecourses, lakes, architecture (government buildings, country houses, bungalows and churches), botanical gardens, vegetation (plants and flowers) and life style. The architecture was in the British Gothic Revival, Tudor Revival, Elizabethan Renaissance Revival, Victorian or Swiss Gothic style and an important aspect of the duplication. 


\section{References}

Anand, M. R. (Ed.). (1997). Splendours of Himalachan Heritage. India, New Delhi: Abhinav Publications.

Biswas. S (2013). Urban Growth Centers in Darjeeling hills of West Bengal: A Geographical Analysis. The Journal of the Bengal Geographer 2(1), 30-48.

Campagnac-Carney, S. L. (2010). Burma Memoires of WWOII. Raleigh, NC: Blue Mist Publications.

Clarke, H. (1881). The English Stations in the Hill Regions of India: Their Value and Importance, with Some Statistics of their Products and Trade. Journal of the Statistical Society of London, 44(3) 528-573.

Clarke, H. (1881). The English Stations in the Hill Regions of India: Their Value and Importance, with Some Statistics of their Products and Trade. Journal of the Statistical Society of London, 44(3) 528-573.

Crossette, B. (1999a). The great hill stations of Asia. New York, NY: Basic Books.

Crossette, B. (1999b). In B. Crossette (Ed.), A Malaysian mix: Penang Hill and Maxwell's Hill, Cameron Highlands, Fraser's Hill. New York, NY: Basic Books, 163-185.

Desai, M., Desai M. \& Lang J. (2012). The Bungalow in Twentieth-Century India. The Cultural Expression of Changing Ways of Life and Aspirations in the Domestic Architecture of Colonial and Post-colonial Society. Farnham, England: Ashgate Publishing.

Emeneau, M. B. (1963). Ootacamund in the Nilgiris: Some Notes. Journal of the American Oriental Society 83(2) 188-193.

Hunt, G. (1967). The Forgotten Land. London, England: G. Bles.

Iyer, P. (1988). Video Night in Kathmandu: And Other Reports from the Not-So-Far East. New York, NY: Random House.

Kam, S. P. (1992). Development and Conservation of Penang Hill. In R.P. Lim \& Lee Sun Win (Eds.), Hill Development: Proceedings of the Seminar. Malayan Nature Society, Kuala Lumpur, 6-15.

Kennedy, D. (1996). The magic mountains: hill stations and the British Raj. Berkeley, CA: University of California Press.

Kishore, B. R. (2003) (Goyal G.C. (Ed.). India. A Travel Guide. India, New Delhi: Fusion Books.

Mannin, E. (1955). Land of the Crested Lion Journey through Modern Burma. $\left(2^{\text {nd }}\right.$ Ed). Norwich, England: Jarrold \& Sons Ltd.

Penang Hill Resort. (1990). Final Master Plan. Submitted to the Government of Penang. For Bukit Pinang Leisure Sdn Bhd. 
Revised Heritage Report (4). (2008). Heritage of Shimla. Town and Country Planning Department Shimla 171009 H.P.

Spate, O. H. K. (1945). The Burmese Village. The Geographical Review XXXV (4). 523-543.

Spencer J. E., \& Thomas, W. L. (1948). The Hill Stations and Summer Resorts of the Orient. Geographical Review, 38(4), 637-651.

Veale, L. (2007). Transforming the Tropics; The Creation of British space in India. Negotiating Space: a Postgraduate Workshop. 16 June 2008. Centre for Advanced Studies. Introduction by Hannah Neate and Jo Pready. UK, Nottingham University.

Ward, B.S. (1837). Memoir of the Vuragherry and Kunnandaven Mountain., Madras Journal of Literature and Science, 6, 280. 